\title{
Watershed prioritization for the identification of spatial hotspots of flood risk using the combined TOPSIS-GIS based approach: a case study of the Jarahi-Zohre catchment in Southwest Iran
}

\author{
Koursh Shirani ${ }^{1}$, Reza Zakerinejad ${ }^{2}, *$ \\ ${ }^{1}$ Agricultural Research, Education and Extension Organization, Soil Conservation and Watershed Management
Research Institute, Iran
2 University of Isfahan, Faculty of Geographical Sciences and Planning, Iran
${ }^{*}$ Corresponding author: r.zakerinejad@geo.ui.ac.ir, reza.zakerinezhad@gmail.com
}

\section{ABSTRACT}

Flash flooding caused by excessive rainfall in a short period of time is one of the worst environmental hazards, especially in arid and semi-arid regions. Watershed prioritisation identifies and ranks the different watersheds in a catchment based on multiple parameters, which play a role in the land and water degradation. This article deals with the prioritization of 24 sub-catchments in the Jarahi-Zohre catchment in southwest Iran by applying the mixed multivariate linear model of TOPSIS. Morphometric parameters, such as the constant of channel maintenance, drainage density, ruggedness number, infiltration index, stream power index, stream frequency, slope, drainage texture rate, relief rate, form factor, bifurcation ratio, as well as the topographic wetness index, were used as TOPSIS input data, along with precipitation information. The results obtained from the weighting analysis show that ruggedness number, slope and rainfall information have the largest impact on flood events. The sub-catchments Seidyon, Emamzadeh Jafar, and Takht Deraza have a high flood risk and should be given the highest priority for soil and water conservation measures. To validate the results, the prioritization scheme was compared to the flood events in recent years.

KEYWORDS

morphometry; flood risk; TOPSIS; GIS

Received: 6 September 2019

Accepted: 15 March 2021

Published: 31 March 2021

Shirani, K., Zakerinejad, R. (2021): Watershed prioritization for the identification of spatial hotspots of flood risk using the combined TOPSIS-GIS based approach: a case study of the Jarahi-Zohre catchment in Southwest Iran. AUC Geographica 56(1), 120-128 https://doi.org/10.14712/23361980.2021.6

(C) 2021 The Authors. This is an open-access article distributed under the terms of the Creative Commons Attribution License (http://creativecommons.org/licenses/by/4.0). 


\section{Introduction}

Flood hazard is a type of natural disaster that affects the lives of many human being (Guzzetti et al. 2005; Penning-Rowsell et al. 2005; Salvati et al. 2010). It is one of the natural disasters that recently affect many areas especially with arid and semi climate around the world. People's lives are lost during these disasters, and infrastructures may be destroyed. Floods are regarded as the most terrible climatic disaster in the world in terms of loss of life and property damages. Floods are basically extreme hydrological events due to heavy precipitation. Floods occur at different intervals and with varying durations. Recently, considerable progress in the subject of fluvial geomorphology has been achieved by quantitative studies of streams, drainage basins and underlain substrates. New insights emerged because of quantitative studies using hydro-geometry and/or hydro-morphometry leading to quantitative measures of the land forms. Obviously, human activities have increased flood risk because of increasing population growth and rapid urban and rural development. Flood events are often more severe in developing countries and they are the most severe limitation for sustainable development.

In many countries particularly in developing countries, the management of sediment-related environmental problems is deprived by a lack of information on the rate of erosion and sediment in river catchments (Zakerinejad, Maerker 2014, 2015). Therefore, flood events may cause strong damages and erode the fertile top soils. Moreover, it is one of the most effective phenomena that leads to decreasing soil productivity and pollution of water resources.

Particularly, arid and semi-arid areas are affected since they have scarce vegetation cover after long dry periods and intensive rainfall events in these regions.

Therefore, there is an urgent need for management of water resource and for controlling flood events in the susceptible areas. Morphometric analysis of catchments provides a quantitative description of the drainage system (Rao et al. 2010). Morphometric analysis and land use parameters can be used to conduct a proper prioritization of watersheds even without the availability of soil maps. Hence, watershed prioritization is an essential need for management of prone areas that allows the identification of spatial hotspots of flood risk.

Many recent studies on morphometric analysis use remote sensing and GIS techniques to assess the flash flood susceptibility of catchments (Ames et al. 2010; Bajabaa et al. 2014; Youssef et al. 2016). Some effective and finite parameters were applied by different authors to evaluate flood risk. These parameters include land use, lithology, soil type, drainage density, distance from river, topographic wetness index (TWI), altitude, slope aspect, slope angle and plan curvature (Biswas et al. 1999; Kia et al. 2012; Bajabaa et al. 2014).
There are only few studies that focus exclusively on the morphometric parameters to prioritizes sub-catchments. Many investigations recently conducted in Iran show that terrain parameters (slope, aspect, SPI, TWI, catchment area, ...) are the most important factors to predict flood events (Khanbabaei et al. 2013; Cao et al. 2016). Various methods have been used for flood susceptibility mapping. In some recent studies methods were applied like multi-criteria evaluation (Balogun et al. 2015), decision tree (DT) analysis (Tehrany et al. 2013), weights-of-evidence (WoE) (Tehrany et al. 2014), artificial neural network (ANN) (Campolo et al. 2003; Kia et al. 2012; Tiwari et al. 2010), or frequency ratio (FR) (Rahmati et al. 2016).

Hence, he main aim of this research is to prioritize 24 sub-catchments of the Jarahi-Zohre in southwest of Iran using morphometric parameters in order to identify the respective flood risk. In this study we apply GIS tools and the TOPSIS (Technique for Order Preference by Similarity to Ideal Solution) model.

\section{Study Area}

The study area is the Jarahi-Zohre catchment, draining into the Persian Gulf (Fig. 1). The study area is located in the southwest of Iran, between $48^{\circ} 16^{\prime}$ to $52^{\circ} 16^{\prime} \mathrm{N}$ and $29^{\circ} 46^{\prime}$ to $31^{\circ} 40^{\prime} \mathrm{E}$, and covers an area of ca. $41,014 \mathrm{~km}^{2}$. The area is located on the interface between the over-thrust and the folded Zagros, which structurally follows the over-thrust Zagros.

The altitude of the area approximately varies from 0 to $3639 \mathrm{~m}$ a.s.l. The Jarahi-Zohre catchment has

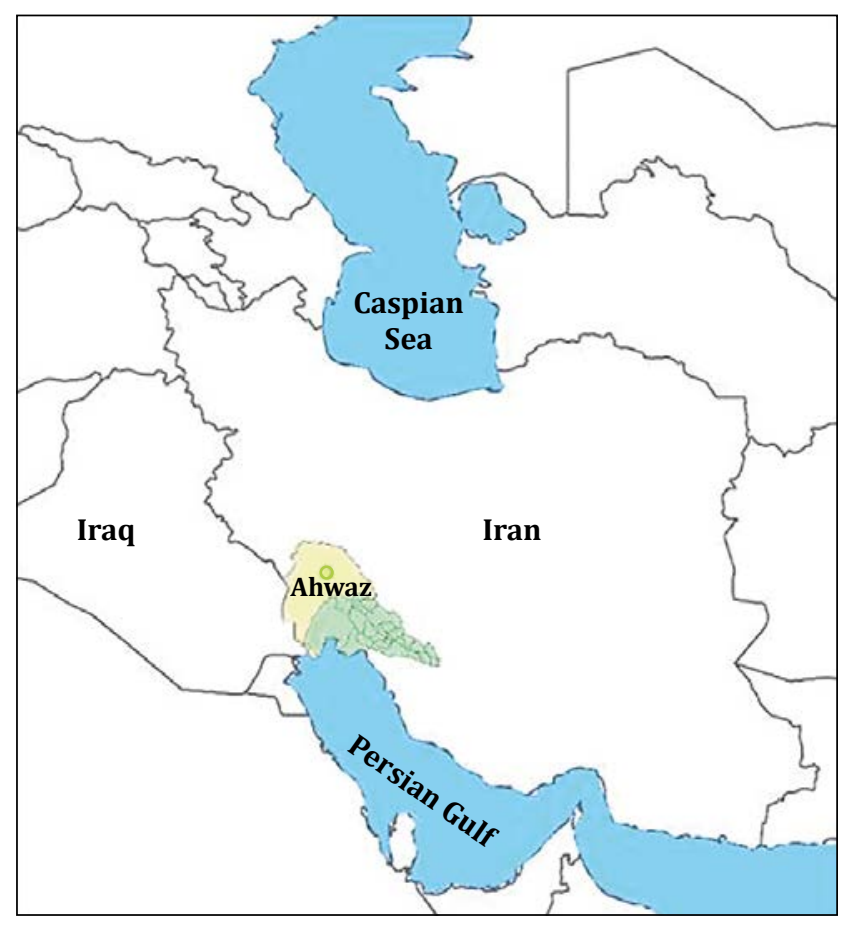

Fig. 1-1 Location of the Jarahi-Zohre catchment in Iran. 


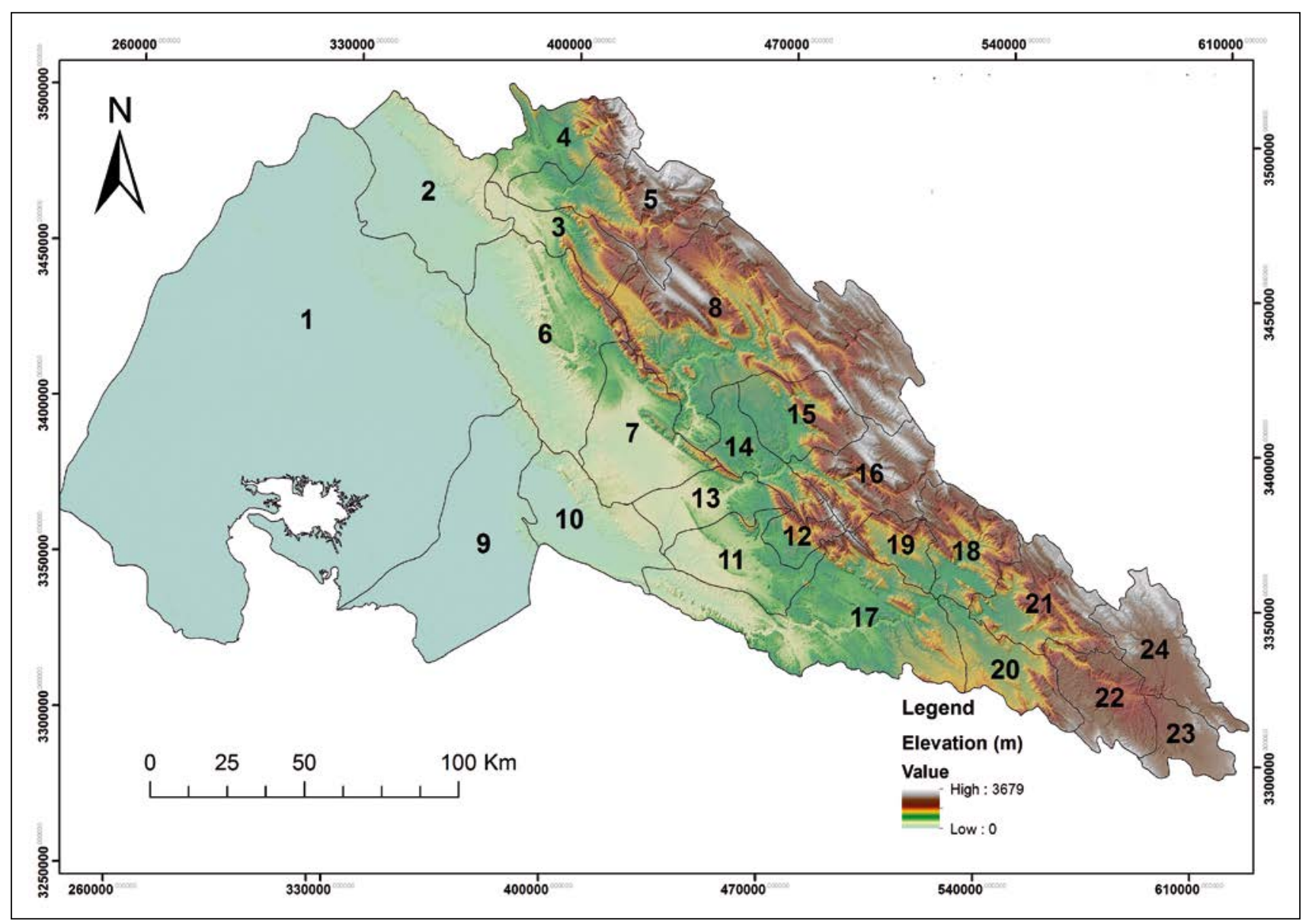

Fig. 1-2 Location of the Jarahi-Zohre catchment in Iran.

The number indicated the name of each sub-catchment (1. Shadegan, 2. Ramhormoz, 3. Daloon, 4. Baghmalek, 5. Sydoon, 6. Jayzan, 7. Bebahan, 8. Takhtedaraz, 9. Handijan, 10. Zydon, 11. Lishtar, 12. Dogonbadan, 13. Khirabad, 14. Sarpari, 15. Dehdasht, 16. Shahbahram, 17. Emamzadeh Jafar, 18. Dashte Rostam, 19. Basht, 20. Norabad, 21. Fahlyn, 22. Saranjilak, 23. Kodyan-Sarga, 23. Ardan-Cheshmeh).

24 sub-catchments, that mostly are located in Khuzestan province in southwest of Iran but some parts of the study area are located in Fars-, Kohgiluyeh-, and the Boyer-Ahmad provinces. The Mediterranean air masses entering from the northwest result in considerable precipitation in the area, which in winter times turns to snow on the higher elevations. The average annual precipitation of the area is $976 \mathrm{~mm}$, the mean temperature is $10.4{ }^{\circ} \mathrm{C}$ (Iranian Water Resources Management Company). The Zohreh River enters the Zeydun plain after the confluence with the Kheir Abad. In the South of Aghajari the Zohreh River it is redirected to the South and passes through the Hendijan (Azarang et al. 2019). The river finally arrives at the Persian Gulf at a location called Chatla. The most parts in east and southeast have mountain areas while the area in west they are mostly flat with low angle slopes.

\section{Methodology}

Digital Terrain Models (DTM) are a gridded digital representation of a terrain, with each pixel value corresponding to a terrain elevation above a specific datum. DTMs are useful to extract morphometric parameters that characterize the terrain morphology and related processes (Wilson, Gallant 2000; Montgomery, Dietrich 1994). In this study we used the ASTER GDEM with $30 \mathrm{~m}$ resolution to extract the morphometric parameters for the whole study area. The Arc Hydro extension in Arc GIS10.4 and SAGA 7.8.0 (System for Automated Geo-Scientific Analyses, Conrad 2006) were used to prepare the ASTER GDEM and to derive the morphometric parameters for our study area. We can differentiate between morphometric parameter describing:

i) the morphology of the surface,

ii) hydrological parameters to describe runoff generation and potential flow pattern,

iii) transport and deposition of sediments,

iv) climatic parameters (Hengl et al. 2003).

For this study we derived a set of topographic indices (Table 1 ) that included: Bifurcation ratio $(\mathrm{Rb})$, Drainage density (Dd), Constant of channel maintenance (C), Stream frequency (Fs), Form factor (Ff), Drainage texture (T), Ruggedness number (Rn), Relief ratio (Rh), Average slope (Sm), Topographic Wetness 
Tab. 1 Formulae for computation of morphometric parameters.

\begin{tabular}{|c|c|c|c|}
\hline & Morphometric parameters & Formula & Reference \\
\hline 1 & Bifurcation ratio $(\mathrm{Rb})$ & $\begin{array}{l}\mathrm{Rb}=\mathrm{Nu} / \mathrm{Nu}+1 \\
\text { where } \mathrm{Nu}=\text { total number of stream segments of order ' } \mathrm{u} \text { ', } \\
\mathrm{Nu}+1=\text { number of segments of the next higher order }\end{array}$ & Sharma et al. 2008 \\
\hline 2 & Drainage density $(\mathrm{Dd})$ & $\begin{array}{l}D d=L u / A \\
\text { where } D d=\text { drainage density, } \\
L u=\text { total stream length of all orders, } \\
A=\text { area of the basin }\left(\mathrm{km}^{2}\right)\end{array}$ & Sharma et al. 2008 \\
\hline 3 & Constant of channel maintenance (C) & $\begin{array}{l}\mathrm{C}=\mathrm{A} / \sum_{i=0}^{i=n} \mathrm{Li}, \\
\text { where } \mathrm{A}=\text { area of the basin, } \mathrm{km}^{2}, \\
\mathrm{Li}=\text { total number of stream segments of order }\end{array}$ & Horton 1945 \\
\hline 4 & Stream frequency (Fs) & $\begin{array}{l}\mathrm{Fs}=\mathrm{Nu} / \mathrm{A}, \\
\text { where } \mathrm{Fs}=\text { stream frequency, } \\
\mathrm{Nu}=\text { total number of streams of streams of all order, } \\
\mathrm{A}=\text { area of the basin, } \mathrm{km}^{2}\end{array}$ & Horton 1945 \\
\hline 5 & Form factor (Ff) & $\begin{array}{l}\mathrm{Ff}=\mathrm{A} / \mathrm{Lb}^{2} \\
\text { where } \mathrm{Ff}=\text { form factor, } \\
A=\text { area of the basin, } \mathrm{km}^{2}, \\
\mathrm{Lb}=\text { basin length }\end{array}$ & Sharma et al. 2008 \\
\hline 6 & Drainage texture $(T)$ & $\begin{array}{l}\mathrm{T}=\mathrm{Nu} / \mathrm{P}, \\
\text { where } \mathrm{Nu}=\text { total number of streams of all orders, } \\
\mathrm{P}=\text { basin perimeter, } \mathrm{km}\end{array}$ & Horton 1945 \\
\hline 7 & Relief ratio (Rh) & $\begin{array}{l}\mathrm{Rh}=\Delta \mathrm{H} / \mathrm{Lb}, \\
\text { where } \Delta \mathrm{H} \text { is the height difference of the catchment, } \\
\mathrm{Lb}=\text { total stream length of all orders }\end{array}$ & Moore et al. 1991 \\
\hline 8 & Ruggeness number (Rn) & $\begin{array}{l}\mathrm{Rn}=\Delta \mathrm{H} \times \mathrm{Dd} \\
\text { where } \Delta \mathrm{H} \text { is the height difference of the catchment, } \\
\mathrm{Dd}=\text { Drainage density }\end{array}$ & Moore et al. 1991 \\
\hline 9 & Average of slope $(\mathrm{Sm})$ & $\begin{array}{l}\mathrm{Sm}=\Delta H / \mathrm{A} \\
\text { where } \Delta H=\text { the height difference of the catchment, } \\
\mathrm{A}=\text { area of the basin, } \mathrm{km}^{2}\end{array}$ & Sharma et al. 2008 \\
\hline 10 & Topographic Wetness Index (TWI) & $\begin{array}{l}\text { TWI }=\ln (a / \operatorname{tag} \beta) \\
\text { where } a=\text { the upslope contributing area, } \\
\beta=\text { the topographic gradient (slope) }\end{array}$ & Olaya, Conrad 2008 \\
\hline 11 & Stream Power Index (SPI) & $\begin{array}{l}\mathrm{SPI}=\mathrm{As} \times \operatorname{tag} \beta \\
\text { where As = specific catchment area, } \\
\mathrm{b}=\text { slope in degree }\end{array}$ & $\begin{array}{l}\text { Moore, Wilson } \\
1992\end{array}$ \\
\hline 12 & Infiltration factor (Ig) & $\begin{array}{l}\text { Ig }=\mathrm{Dd} \times \mathrm{Fs}, \\
\text { where } \mathrm{Dd}=\text { drainge density, } \\
\text { Fs = stream frequency }\end{array}$ & Zavoiance 1985 \\
\hline 13 & The mean perceptions of the catchment ( $\mathrm{Rm})$ & $\mathrm{Rm}=\mathrm{Rd} / \mathrm{A}$ & - \\
\hline
\end{tabular}

Index (TWI), Stream Power Index (SPI), as well as Infiltration (Ig) and mean perception (1985-2012). The listed indices were used in the prioritization procedure as as input information for the TOPSIS model.

Table 2 shows these indices and the respective methods applied for their delineation from the ASTER GDEM. The ASTER GDEM was preprocessed with low pass filtering to extract artefacts and errors like local noise and terraces (Maerker, Heydari Guran 2009; Zakerinejad, Maerker 2013; Vorpahl et al. 2012). Subsequently, the ASTER GDEM was hydrologically corrected eliminating sinks using the algorithm proposed by Planchon and Darboux (2001).

After calculating and mapping the topographic parameter, in order to prioritize 24 sub-catchment areas, the multivariate linear mixed-TOPSIS model was applied for the study area. In the next step the model was validated using information on recent flood events existing for each sub-catchment.

\subsection{TOPPIS Model}

In this research, the TOPSIS model (Technique for Order of Preference by Similarity to Ideal Solution) (Hwang, Yoon, 1981) was used as screening tool to derive a prioritization of the watersheds.

This model is a multi-criteria decision analysis method and it is based on the concept that the chosen alternative should have the shortest distance to the positive ideal solution (PIS) and the longest distance to the negative ideal solution (NIS). The TOPSIS model is flexible in terms of input data and hence, a valuable tool for land use planner and for monitoring purposes in changing landscapes. The TOPSIS approach has 
been successfully applied in different environments (e.g. Badar et al. 2013; Biswas et al. 1999; Chu, Lin 2009), although it is not as widely applied as other multi attribute methods. This model is an effective method in handling Multicriteria Decision-Making (MCDM). The positive ideal solution attempts to seek the maximization of benefit criteria and the minimum of the cost criteria, whereas the negative ideal solution is just the opposite.

\subsection{The structures of TOPSIS model}

Suppose that there is an MCDM problem with $\mathrm{m}$ alternatives and $\mathrm{n}$ criteria, and the decision matrix is $\left[\mathrm{x}_{\mathrm{ij}}\right]_{\mathrm{m} \times \mathrm{n}}$. The procedure of TOPSIS consists of the following steps:

1. Calculate the normalized decision matrix, this step transforms various attribute dimensions into non-dimensional attributes, which allows comparisons across criteria. Normalize scores or data as follows:

$$
n_{i j}=\frac{x_{i j}}{\sqrt{\sum_{i=1}^{m} x_{i j}^{2}}}, i=1, \ldots, m, j=1, \ldots, n
$$

2. Calculate the weighted normalized decision matrix, assume we have a set of weights for each criteria $w_{i}$ for $j=1, \ldots, n$. Multiply each column of the normalized decision matrix by its associated weight

$v_{i j}=w_{j} n_{i j}, i=1, \ldots, n$

where $\mathrm{w}_{\mathrm{j}}$ is the weight of the $\mathrm{j}$-th criterion, and $\sum_{j=1}^{n} w_{j}=1$.

3. Determine the positive ideal $\left(\mathrm{A}^{+}\right)$and negative ideal $\left(\mathrm{A}^{-}\right)$solution.

$$
\begin{aligned}
& A=\left\{v_{1, \ldots,}^{+} v_{n}^{+}\right\}=\left\{\max v_{i j}, j=1, \ldots, n\right\} \\
& A=\left\{v_{1, \ldots,}^{-} v_{n}^{-}\right\}=\left\{\min v_{i j}, j=1, \ldots, n\right\}
\end{aligned}
$$

4. Calculate the separation measures, using the dimensional Euclidean distance. The separation of each alternative from PIS is given by

$d_{i}^{+}=\left\{\sum_{j=1}^{n}\left(v_{i j}-v_{j}^{+}\right)^{2}\right\}^{\frac{1}{2}}, \mathrm{i}=1, \ldots, \mathrm{m}$

Similarly, the separation from NIS is given by

$d_{i}^{-}=\left\{\sum_{j=1}^{n}\left(v_{i j}-v_{j}^{-}\right)^{2}\right\}^{\frac{1}{2}}, \mathrm{i}=1, \ldots, \mathrm{m}$

5. Calculate the relative closeness to the ideal solution.

$$
C_{i}=\frac{d_{i}^{-}}{d_{i}^{+}+d_{i}^{-}}, \mathrm{i}=1, \ldots, \mathrm{m}
$$

6. Rank the preference according to $\mathrm{C}_{\mathrm{i}}$.
For the validation of the TOPSIS approach, the prioritization of each sub-catchment to flood risk was compared to the recent flood events using the Frequency Index (FI).

\section{Result and discussion}

Terrain analysis or morphometry is yielding valuable quantitative information on the earth's surface and on processes forming the earth surface forms and features. Hence, these techniques provide useful information for the evaluation of watersheds and their management.

In this study, Morphometric parameters (bifurcation ratio, drainage density, constant of channel maintenance, stream frequency, form factor, drainage texture, ruggedness number, relief ratio, average slope, topographic wetness index, stream power index, infiltration factor, and rainfall factors) were used as input parameters for the TOPSIS approach in order to derive a proper prioritization of the watershed to identify the spatial hotspots of flood risk of each sub-catchments in our case study in the southwest of Iran.

In this study, we used the multivariate regression for weighting the criteria since flood data were available for the whole study area.

After the calculation of the flood event frequency, each sub-catchment was ranked attributing with the score between 0 and 10. Afterwards we processed each scores for 534,231 homogenous units and 13 morphometric parameters using SPSS software. Between different multivariate regression, the ENTER regression with 93\% confidence level was selected.

Figure 2 shows the overlaid flood events points and homogenous units map and also Equation 8 shows the results from stochastic analysis with, $\mathrm{R}=0.96$ for the study area.

$$
\begin{aligned}
& \mathrm{Y}=0.07-0.0018 \mathrm{X}_{\mathrm{C}}-0.0032 \mathrm{X}_{\mathrm{Dd}}+0.68 \mathrm{X}_{\mathrm{Rn}}+ \\
& 0.00056 \mathrm{X}_{\mathrm{S}}+0.00089 \mathrm{X}_{\mathrm{SPI}}-0.0031 \mathrm{X}_{\mathrm{Fs}}+0.24 \\
& \mathrm{X}_{\text {Slope }}-0.0057 \mathrm{X}_{\mathrm{Rt}}+0.0023 \mathrm{X}_{\mathrm{Rh}}+0.0041 \mathrm{X}_{\mathrm{Ff}} \\
& +0.016 \mathrm{X}_{\text {Rain }}-0.018 \mathrm{X}_{\mathrm{Rb}}+0.0019 \mathrm{X}_{\mathrm{TWI}}
\end{aligned}
$$

The results for the weighting criteria applying the linear regression shows that the ruggedness number, slope and rainfall with $0.068,0.024$ and 0.16 rated as the highest impact on flood events in the study area (Table 2).

In some other studies, these parameters have been the most important factor for the flood events (Khayri Zadeh et al. 2012; Saghafian et al. 2008).

While drainage texture, drainage density and stream frequency respectively, with values of $-0.0057,-0.0032$ and -0.0032 respectively have the lowest impact on flood events in the study area. The other parameters fall between these maximum and minimum ranking values highest and lowest ranking. 
Tab. 2 The results of multivariate regression analysis.

\begin{tabular}{|l|c|c|c|}
$\begin{array}{l}\text { Morph metric } \\
\text { parameters }\end{array}$ & $\begin{array}{c}\text { Mark } \\
\text { equations }\end{array}$ & Weight & $\begin{array}{c}\text { The significance } \\
\text { level }\end{array}$ \\
\hline $\begin{array}{l}\text { Constant of channel } \\
\text { maintenance }\end{array}$ & $\mathrm{X}_{\mathrm{C}}$ & -0.00180 & 0.0010 \\
\hline Drainage density & $\mathrm{X}_{\mathrm{Dd}}$ & -0.03200 & 0.0010 \\
\hline Ruggedness number & $\mathrm{X}_{\mathrm{Rn}}$ & 0.06800 & 0.0010 \\
\hline Infiltration factor & $\mathrm{X}_{\mathrm{S}}$ & 0.00056 & 0.0000 \\
\hline Stream Power Index & $\mathrm{X}_{\mathrm{SPI}}$ & 0.00089 & 0.0010 \\
\hline Stream frequency & $\mathrm{X}_{\mathrm{Fs}}$ & -.003100 & 0.0001 \\
\hline Slope & $\mathrm{X}_{\mathrm{Slope}}$ & .024000 & 0.0000 \\
\hline Drainage texture & $\mathrm{X}_{\mathrm{Rt}}$ & -.005700 & 0.0010 \\
\hline Relief ratio & $\mathrm{X}_{\mathrm{Rh}}$ & .002300 & 0.0010 \\
\hline Form fact & $\mathrm{X}_{\mathrm{Ff}}$ & .004100 & 0.0000 \\
\hline Rainfall & $\mathrm{X}_{\mathrm{Rain}}$ & .016000 & 0.0000 \\
\hline Bifurcation ratio & $\mathrm{X}_{\mathrm{Rb}}$ & -.018000 & 0.0000 \\
\hline $\begin{array}{l}\text { Topographic } \\
\text { Wetness Index }\end{array}$ & $\mathrm{X}_{\mathrm{TWI}}$ & .019000 & 0.0000 \\
\hline
\end{tabular}

Sub-catchment according to the equations applied in step 3 of the TOPSIS algorithm, the positive ideal solution $\left(\mathrm{A}^{+}\right)$and negative ideal solution $\left(\mathrm{A}^{-}\right)$are calculated for all criteria, and then a layer is created for each $v+j$ and $v-j$. The separation of each alternative from the positive ideal solution layer and the separation of each alternative from the negative ideal solution layer are calculated based on Equations 3-6, respectively (Table 3).

According to table 3 the result of the ranking procedure of each sub-catchment indicates that the Sydon, Emamzadeh Jafar and Takhte Daraz sub-catchments have the shortest distance to the positive ideal $(0.0097,0.0098,0.0095)$ and highest distance to the negative ideal $(0.7745,0.769,0.7625)$, therefore they are ranked in the first three rating classes for flood risk. Therefore, these susceptible sub-catchments should get more attentions and should be prioritized by land use planner and for a sustainable landuse management.

On the other hand, the Jayzan, Saranjilak and Shadegan subcatchments show the highest distance to the positive ideal $(0.0065,0.0063,0.0059)$ and shortest distance to the negative ideal $(0.0080$, $0.0081,0.008$ ) and are characterized by the lowest scoring of $0.5532,0.5633$ and 0.5766 respectively. Thus, they show the lowest flood risk.

The Sydon sub-catchment shows high flooding risk expressed by high values of the applied morphometric parameters. In turn, these parameters have a direct relationship with flood events. Therefore, these sub-catchments has the highest flood risk. The Sydoon

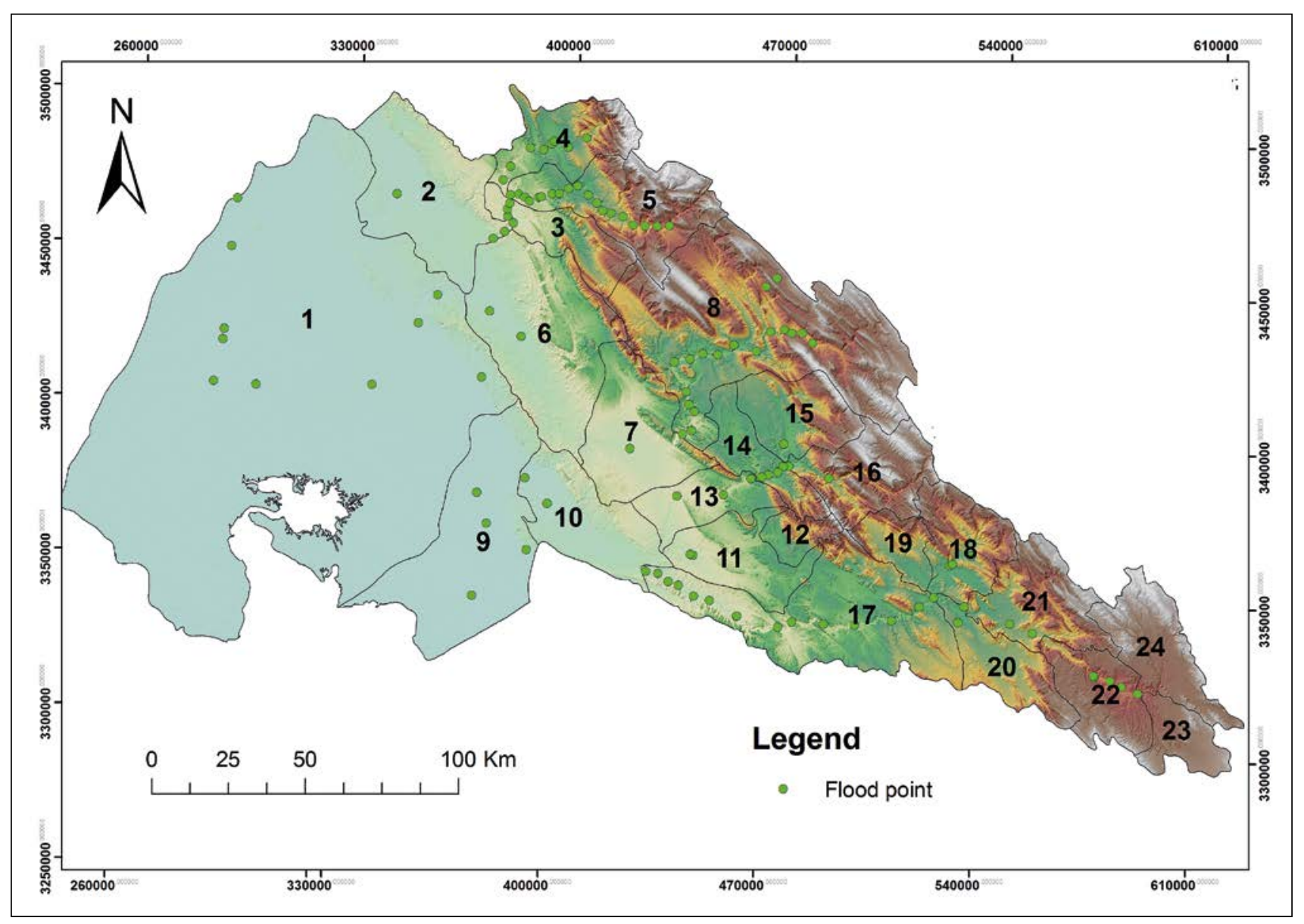

Fig. 2 The distribution of flood events in the study area. 
Tab. 3 The normal matrix of the all sub-catchments in the study area.

\begin{tabular}{|c|c|c|c|c|c|}
\hline Sub-catchment & $\mathrm{D}_{\mathrm{i}}^{+}$ & $D_{i}^{-}$ & $C l_{i+}$ & Ranking & Flood frequency \\
\hline Shadegan & 0.0059 & 0.0080 & 0.5766 & 22 & 2 \\
\hline Ramhormoz & 0.0054 & 0.0081 & 0.5996 & 19 & 1 \\
\hline Dalon & 0.0031 & 0.0093 & 0.7497 & 6 & 3 \\
\hline Bagh Malek & 0.0032 & 0.0096 & 0.7470 & 7 & 4 \\
\hline Sydon & 0.0028 & 0.0097 & 0.7745 & 1 & 14 \\
\hline Jayzan & 0.0065 & 0.0080 & 0.5532 & 24 & 1 \\
\hline Bebahan & 0.0035 & 0.009 & 0.7180 & 13 & 1 \\
\hline Takhte Daraz & 0.0029 & 0.0095 & 0.7625 & 3 & 12 \\
\hline Hendijan & 0.0057 & 0.0080 & 0.5848 & 20 & 2 \\
\hline Zidon & 0.0057 & 0.0079 & 0.5801 & 21 & 1 \\
\hline Lishtar & 0.0038 & 0.0089 & 0.6964 & 16 & 1 \\
\hline Dogonbadan & 0.0030 & 0.0094 & 0.7559 & 4 & 2 \\
\hline Khirabad & 0.0035 & 0.0089 & 0.7145 & 15 & 2 \\
\hline Sarperi & 0.0030 & 0.0094 & 0.7541 & 5 & 5 \\
\hline Dehdasht & 0.0031 & 0.0092 & 0.7457 & 8 & 1 \\
\hline Shahbaram & 0.0034 & 0.0091 & 0.7281 & 11 & 2 \\
\hline Emamzdadeh Jafar & 0.0029 & 0.0098 & 0.7690 & 2 & 12 \\
\hline Dashte Rostam & 0.0035 & 0.0089 & 0.7166 & 14 & 2 \\
\hline Basht & 0.0033 & 0.0090 & 0.7295 & 10 & 0 \\
\hline Norabad Mamsani & 0.0039 & 0.0086 & 0.6865 & 17 & 1 \\
\hline Fahlian & 0.0035 & 0.0089 & 0.7188 & 12 & 2 \\
\hline Saranjilak & 0.0063 & 0.0081 & 0.5633 & 23 & 1 \\
\hline Kodian & 0.0044 & 0.0084 & 0.6554 & 18 & 0 \\
\hline Ardakan & 0.0033 & 0.0091 & 0.7343 & 9 & 1 \\
\hline
\end{tabular}

sub-catchment shows especially steep slopes (39.4\%) indicating high runoff velocities and quick drainage. Thus, as stated by Tucker and Bras (1998) the hill slope processes control the watershed hydrology.

The high value of drainage density indicates the poor vegetation and low infiltration rate while the low drainage densities are related to highly permeable soils and coarse textures (Horton 1945; Sharma et al. 2008). Stream frequency in these high rated flood risk sub-catchments implies increasing stream numbers with respect to increasing drainage density (Bhattacharjee 2016).

The ruggedness number reflects the topography and hydrological characteristics of the catchments and is directly related to flooding events (Aher et al. 2014). The relief ratio has a direct relationship with the river slope, basin hydrological processes and soil erosion processes (Srivastava et al. 2003). The form factor describes the direct impact of flows in the watershed in terms of water dischrage and sediment yield. The form factor is identical to unity when the basin shape is a square, and decreases with increasing elongation (Zavoianu 1985). The higher bifurcation ratio of the Sydon sub-catchment is also responsible for early hydrograph peaking during the storm events compared to the others sub-catchments.

\section{Conclusions}

Flood events can dramatically erode and destroy fertile top soil layers and are the main cause of desertification in many parts of arid and semi-arid areas in the world.

Watershed prioritization for the identification of spatial hotspots of flood risk using a combined GIS-TOPSIS based approach is a cost effective procedure requiring a limited amount of input data and hence, is a is very useful tool for land use planner and basin managers. We applied the method to assess the influence of watershed characteristics on the flood risk in the Zohreh and Jarahi catchment in southwest of Iran.

The parameters used in this study are include, bifurcation ratio, drainage density, constant of channel maintenance, stream frequency, form factor drainage texture, ruggedness number, relief ratio, infiltration factor, rainfall, topographic wetness index, stream power index and average slope parameters. Since there is a close relationship between the morphometric parameters and the mean annual floods (Cao et al. 2016), we know that sub-catchments with high values of morphometric parameters are more prone to flood risk. 
The results of the prioritization parameters using multivariable linear regression showed that especially the ruggedness, slope and rainfall indices have the highest impact on the occurrence of flood events in our study area.

The Sydon, Emamzadeh Jafar and Takhte Daraz sub-catchments show a high risk of flood hazard compared to the other sub-catchments. Therefore, land use planners and basin managers should give more attention to LULC management particularly, in these high flood risk areas. In order to validate the results of the TOPSIS model, the prioritization of sub-catchments of flood risk were compared to recent flood event data.

The overlay of the spatial distribution of flood events with the sub-catchments show that the threesub-catchments Sydon, Emamyadeh Jafar and Takhte Daraz have a higher number of flood events than the other sub-catchments. Consequently, there is a good correspondence of the model results and the validation information. We conclude that the TOPSIS results can be used for future studies and the model be applied in other watershed areas.

In fact, using morphometric parameters we can prioritize the watershed in order to develop protection plans for each sub-catchments with low cost and time effort (Aher et al. 2014; Javed et al. 2009).

\section{Acknowledgements}

We would like to thank to Prof. Michael Maerker from the University of Pavia, to help us to improve the quality of this article.

\section{References}

Aher, P., Adinarayana, J., Gorantiwar, S. D. (2014): Quantification of morphometric characterization and prioritization for management planning in semi-arid tropics of India: A remote sensing and GIS approach. Journal of Hydrology 511, 850-860, https://doi.org /10.1016/j.jhydrol.2014.02.028.

Akram, J., Mohd, Y. K., Rizwan, A. (2009): Prioritization of sub-watersheds based on morphometric and land use analysis using remote sensing and GIS techniques. Journal of the Indian Society of Remote Sensing 37, 261(2009), http://dx.doi.org/10.1007 /s12524-009-0016-8.

Ames, D. P., Rafn, E. B., Van Kirk, R., Crosby, B. (2009): Estimation of stream channel geometry in Idaho using GIS-derived watershed characteristics. Environmental Modeling and Software 24(3), 444-448. http://dx.doi .org/10.1016/j.envsoft.2008.08.008.

Azarang, F., Shafaei, Bejestan, M., Jafari, G., Karami, M. (2019): The application of global experiences in evaluation of mining zone: Case study the Zohreh River. Journal of Water and Land Development 41, 19-30, http://dx.doi.org/10.2478/jwld-201 9-0023.
Badar, B., Romshoo, S. A., Khan, M. A. (2013): Integrating biophysical and socioeconomic information for prioritizing watersheds in a Kashmir Himalayan lake: a remote sensing and GIS approach. Environmental Monitoring and Assessment 185, 6419-6445, http:// dx.doi.org/10.1007/s10661-012-3035-9.

Biswas, S., Sudhakar, S., Desai, V. R. (1999): Prioritization of sub watersheds based on morphometric analysis of drainage basin - A remote sensing and GIS approach. Journal of the Indian Society of Remote Sensing 27, 155(1999), http://dx.doi.org/10.1007/BF02991569.

Bajabaa, S., Masoud, M., Al-Amri, N. (2014): Flash flood hazard mapping based on quantitative hydrology, geomorphology and GIS techniques (case study of Wadi Al-Lith, Saudi Arabia). Arabian Journal of Geosciences 7, 2469-2481, http://dx.doi.org/10.1007 /s12517-013-0941-2.

Chen, C., Peihua, X., Yihong W., Jianping, C., Lianjing, Z., Cencen, N. (2016): Flash flood hazard susceptibility mapping using frequency ratio and statistical index methods in coalmine subsidence areas. Sustainability 8(9), 948, http://dx.doi.org/10.3390/su8090948.

Chu, T. C., Lin, Y. C. (2009): An interval arithmetic based fuzzy TOPSIS model. Expert Systems with Applications 8(36), 10870-10876. http://dx.doi.org/ 10.1016/j.eswa .2009 .01 .083 .

Campolo, M., Soldati, A., Andreussi, P. (2003): Artificial neural network approach to flood forecasting in the river Arno. Hydrological Sciences Journal 48(3), 381-398, https://doi.org/10.1623/hysj.48.3.381.45286.

Guzzetti, F., Stark, C. P., Salvati, P. (2005): Evaluation of flood and landslide risk to the population of Italy. Environmental Management 36, 15-36, http://dx.doi .org/10.1007/s00267-003-0257-1.

Hengl, T., David, G., Rossiter, T. (2003): Supervised landform classify- cation to enhance and replace photointerpretation in semi detailed soil survey. Soil Science Society of America Journal 67(6), 1810-1822, http://dx.doi.org/10.2136/sssaj2003.1810.

Horton, R. E. (1945): Erosional development of streams and their drainage basins; hydrological approach to quantitative morphology. GSA Bulletin 56(3), 275-370, https://doi.org/10.1130/0016-7606(1945)56[275: EDOSAT]2.0.CO;2.

Hwang, C. L., Yoon, K. (1981): Multiple Attribute Decision Making: Methods and Applications. Springer, Berlin, Heidelberg, https://doi.org/10.1007 /978-3-642-48318-9.

Kia, M. B., Pirasteh, S., Pradhan B., Mahmud A. R., Sulaiman, W. N. A., Moradi, A. (2012): An artificial neural network model for flood simulation using GIS: Johor River Basin, Malaysia. Environmental Earth Sciences 67, 251-264, https://doi.org/110.1007/s12665-011-1504-z.

Khanbabaei, Z., Karam, A., Rostamizad, G. (2013): Studying relationships between the fractal dimension of the drainage basins and some of their geomorphological characteristics. International Journal of Geosciences 4(3), 636-642, https://doi.org/10.4236/ijg.2013.43058.

Khayri, Z. M., Maleki J., Hamid, A. (2012): Flood hazard zonation using ANP model in Mardagh chay basin. Quantitative Geomorphology 3, 39-56. [Persian].

Javed, A., Khanday, M. Y., Ahmed, R. (2009): Prioritization of watersheds based on morphometric and land use analysis using RS and GIS techniques. Journal of the 
Indian Society of Remote Sensing 37, 261(2009), https://doi.org/10.1007/s12524-009-0016-8.

Maerker, M., Heydari Guran, S. (2009): Application of data mining technologies to predict Paleolithic site locations in the Zagros Mountains of Iran. Computer Applications to Archaeology, Williamsburg, Virginia, USA, March 22-26.

Moore, I. D., Grayson, R. B., Ladson, A. R. (1991): Digital terrain modelling: a review of hydrological, geomorphological and biological applications. Hydrological Processes 5(1), 3-30, https://doi.org /10.1002/hyp.3360050103.

Saghafian, B., Farazjoo, H., Bozorgy, B., Yazdandoost, F. (2008): Flood intensification due to changes in land use. Water Resources Management 22, 1051-1067, https:// doi.org/10.1007/s11269-007-9210-z.

Planchon, O., Darboux, F. (2001): A fast, simple and versatile algorithm to fill the depressions of digital elevation models. Catena 46(2-3), 159-176, https://doi.org /10.1016/S0341-8162(01)00164-3.

Penning-Rowsell E., Floyd P., Ramsbottom, D., Surendran S. (2005): Estimating injury and loss of life in floods: A deterministic framework. Natural Hazards 36, 43-64, https://doi.org/10.1007/s11069-004-4538-7.

Rahmati, O., Pourghasemi, H. R., Zeinivand, H., (2016): Flood susceptibility mapping using frequency ratio and weights-of-evidence models in the Golastan province, Iran. Geocarto International 31(1), 42-70, https://doi .org/10.1080/10106049.2015.1041559.

Srivastava, V. K. (2003): The role of GIS in natural resources management. In: Thakur, B. (Ed.). Perspectives in resource management in developing countries. Concept Publishing Company, New Delhi, 479-484.

Sharma, S., Tignath, S., Mishra S. (2008): Morphometric analysis of drainage basin using GIS approach. J.N.K.V.V. Research Journal 42(1), 91-95, https://doi.org/10 $.24327 /$ IJRSR.

Salvati, P., Bianchi, C., Rossi, M., Guzzetti, F. (2010): Societal landslide and flood risk in Italy. Natural Hazard and Earth System Sciences 10(3), 465-483, https://doi.org /10.5194/nhess-10-465-2010.

Tehrany, M. S., Pradhan, B., Jebur, M. N. (2013): Spatial prediction of flood susceptible areas using rule-based decision tree (dt) and a novel ensemble bivariate and multivariate statistical models in GIS. Journal of
Hydrology 504, 69-79, https://doi.org/10.1016 /j.jhydrol.2013.09.034.

Tehrany, M. S., Pradhan, B., Jebur, M. N. (2014): Flood susceptibility mapping using a novel ensemble weightsof-evidence and support vector machine models in GIS. Journal of Hydrology 512, 332-343, https://doi.org /10.1016/j.jhydrol.2014.03.008.

Tiwari, M. K., Chatterjee, C. (2010): Uncertainty assessment and ensemble flood forecasting using bootstrap based artificial neural networks (Banns). Journal of Hydrology 382(1-4), 20-33, https://doi.org/10.1016/j.jhydrol .2009.12.013.

Wilson, J. P., Gallant, J. C. (2000) Digital terrain analysis. In: Wilson, J. P., Gallant J. C. (Eds.), J. Wiley, New York, 1-27.

Wang, C. L., Yoon, K. (1981): Multiple attribute decision making-methods and applications. Berlin, Heidelberg, Springer, https://doi.org/10.1007 /978-3-642-48318-9_3.

Youssef, A. M., Pradhan, B., Sefry, S. A. (2016): Flash flood susceptibility assessment in Jeddah city (Kingdom of Saudi Arabia) using bivariate and multivariate statistical models. Environmental Earth Sciences 75, 12(2016), https://doi.org/10.1007/s12665-015-4830-8.

Vorpahl, P., Elsenbeer H., Maerker, M., Schroeder B. (2012): How can statistical models help to determine driving factors of landslides. Ecological Modelling 239, 27-39, https://doi.org/10.1016/j.ecolmodel.2011.12.007.

Zakerinejad, R., Maerker, M. (2014): Prediction of Gully erosion susceptibilities using detailed terrain analysis andmaximum entropy modeling: a case study in the Mazayejan Plain, Southwest Iran. Geogr. Fis. Dinam. Quat 37, 67-76, https://doi.org/10.4461/GFDQ.2014.37.7.

Zakerinejad, R., Maerker, M. (2015): An integrated assessment of soil erosion dynamics with special emphasis on gully erosion in the Mazayjan basin, southwestern Iran. Natural Hazards 79, 25-50, https:// doi.org/10.1007/s11069-015-1700-3.

Zakerinejad, R., Omran, A., Hochschild, V., Maerker, M. (2018): Assessment of gully Erosion in relation to lithology in the Southwestern Zagros Mountains, Iran using Aster data, GIS and Stochastic Modeling. Geogr. Fis. Dinam. Quat 42, 95-104, https://doi.org/10.4461 /GFDQ.2018.41.15.

Zavoiance, I. (1985): Morphometry of drainage basins (Developments in water science). Elsevier, Amsterdam. 